\title{
2 An analysis of gender equality jurisprudence by Kenyan courts since the enactment of the 2010 constitution
}

\author{
Nancy Baraza, PhD
}

\section{Introduction}

Since independence, gender inequality due to patriarchy were the norm in Kenya. Generally, society was characterized by a discriminatory social system coupled with negative stereotypes against women (Nzomo, 2018, p.54). Kenyan courts sustained these social norms by failing to protect the human rights of women (Kameri-Mbote, 2018, p.23). Women suffered unmitigated discrimination, especially in matters of inheritance, land ownership, marriage, and sharing of matrimonial property, among other areas. This exposed the majority of them to poverty (McCullough et al., 2016, p.4). Discrimination against women was caused partly by the normative deficiencies of the then Constitution and a lack of judicial will and know-how on the part of judges to interpret the law to favor promotion of human rights, especially those of women. Nzomo rightly notes that the independence Constitution provided for and legitimized patriarchy and discrimination against women in issues of matrimonial property ownership, and devolution of property on the death of a spouse, by allowing customary law to apply to the detriment of the female gender (Nzomo, 1991, p.3).

The economic impact of discrimination against women with regard to property ownership in Kenya has persisted to date. A 2016 Gender and Poverty Assessment by the World Bank (World Bank, 2018), for instance, found that currently, Kenyan women are less likely than men to own land or housing property. Only $12 \%$ of women between the ages of 20 and 49 reported any individual ownership of land, compared with $39 \%$ of men. In the realm of housing, men are $32 \%$ more likely to have sole ownership. The implications of women's marginalization in property and land ownership cannot, therefore, be overstated. Research carried out by the World Bank has shown that insecure land tenure can lead to economic inefficiency, especially for women, who have in some countries in Africa been shown to under-invest in their land, which can lead to them realizing substantially lower agricultural yields. This is true of Kenyan women, who are condemned to poverty due to precarious land ownership and access.

The Constitution of Kenya 2010 (hereinafter referred to as the Constitution), however, seeks to change this paradigm. Normatively, the constitution contains far-reaching commitments to a wide range of rights and an ambitious vision of social equity and has the potential to address historical injustices and grievances 


\section{Nancy Baraza}

suffered by women (Baraza, 2018a, p.75). It provides for national values and principles of governance that bind all state organs and state officers, including the courts and judicial officers (Fitzgerald, 2010, p.62). These values and principles include human dignity, equity, social justice, inclusiveness, equality, human rights, non-discrimination, and protection of the marginalized. State organs are enjoined by the constitution to take all these values into account whenever they interpret or apply the Constitution (Fitzgerald, 2010, p.3). Further, the Constitution requires the judiciary to promote the gender equality principle and fairness through transformative judicial decision-making (Baraza, 2018a, p.76). Article 259 specifically lays down the rule of judicial interpretation as follows:

This Constitution shall be interpreted in a manner that promotes its purposes, values, and principles; advances the rule of law, and human rights and fundamental freedoms in the Bill of Rights; permits the development of the law, and contributes to good governance.

To buttress the Constitution, the Supreme Court of Kenya has reaffirmed the requirement under Article 259. In its Advisory Opinion No. 2 of 2011 (In the Matter of Interim Independent Electoral Commission [2011] eKLR), the Supreme Court ruled that the constitution, which is the supreme law of the country, calls for a transformative and purposive approach in their judicial decision-making. In a unanimous decision, the seven justices of the Supreme Court, Justices Willy Mutunga (Chief Justice), Nancy Baraza (Deputy Chief Justice), Jackton Ojwang, Smokin Wanjala, Philip Tunoi, Njoki Ndungu, and Mohammed Ibrahim affirmed the provisions of the constitution on interpretation, noting that it should be transformative. The Supreme Court confirmed that the Constitution requires the courts, in interpreting the Bill of Rights, to promote the values that underlie an open and democratic society, based on human dignity, equality, equity, and freedom, and the spirit, purport, and objects of the Bill of Rights, thus setting the pace for other courts to adopt transformative decision-making in interpreting the principles of the Constitution.

Consequential legislation to the Constitution has also been enacted since 2010. This includes the Marriage Act, the Matrimonial Property Act, the Protection from Domestic Violence Act, and the Land Act, among others. Together with the constitution, these laws are crucial to addressing women's marginalization. Since 2010, the courts have been making decisions in matters critical to gender equality and gender justice in line with the constitutional and the new laws (Kameri-Mbote \& Muriungi, 2016, p.93). Opinions, however, vary on how well these recent court decisions uphold gender equality in areas that have perpetuated discrimination and gender inequality. There is scanty literature analyzing judicial decisions since 2010 to gauge the courts' fidelity to the Constitution's principles of gender equality. This chapter seeks to fill that gap.

The chapter is organized in six parts. The first part gives an overview of the constitutional provisions relevant to gender equality. The second part discusses transformation as a theory and its relevance to the discussions at hand. The third 
part is an exploration of the courts' decisions on marriage, inheritance, domestic violence, access to matrimonial property, and inheritance prior to the enactment of the 2010 constitution. The fourth part explores court decisions in similar areas since the promulgation of the Constitution in 2010. The fifth part discusses some possible threats to the transformative work by the judiciary. The sixth part gives a conclusion to the chapter.

\section{Gender equality in the Constitution}

The vision of social equity and gender justice enshrined in the Constitution marks a break from a past characterized by gender discrimination and inequality (Mutunga, 2015, p.5). Several articles of the constitution entrench gender equality and the demands of social justice in areas of equal treatment with men, equitable access to land, recognition of equality of ownership of matrimonial property, protection from gender-based violence (GBV), inheritance and equality in marriage, and women's equitable participation in elective and appointive positions in the country (Fitzgerald, 2010, p.3). Equality is listed as one of six essential values upon which governance should be based. These expressions of principle are given legal force in Article 10, which includes equity, social justice, equality, non-discrimination, and "protection of the marginalized" among the national values and principles of governance that are to be used in applying and interpreting the Constitution and other laws, and in making or implementing policy decisions.

Of importance is Article 27 of the Constitution. The right to equality and non-discrimination as expressed in Article 27 of the Constitution represents a substantial improvement on the right as provided in Article 82 of the previous constitution (Fitzgerald, 2010, p.3). The Article begins with a guarantee of equality before the law and equal protection and benefit of the law, a guarantee that was not present in the previous constitution. Moreover, equality is defined as including "full and equal enjoyment" of all rights and freedoms. These provisions provide important additional protection, which goes beyond the protection from discrimination provided in Article 27 (4). Article 27 (4) prohibits discrimination on an extensive list of specified grounds: "race, sex, pregnancy, marital status, health status, ethnic or social origin, color, age, disability, religion, conscience, belief, culture, dress, language or birth." The list grants substantially increased protection to women (Fitzgerald, 2010, p.3). Article 27 (6) creates a duty of affirmative action, a concept defined in Article 260, which obligates the State to take legislative and other measures, including but not limited to affirmative action programs and policies designed to redress any disadvantage suffered by individuals or groups as a result of past discrimination. Article 27 (8) requires the state to take measures to ensure that "not more than two-thirds of the members of elective or appointive bodies" are of the same gender. Separate provisions create reserved places for women in the National Assembly, Senate, and County Assemblies. These provisions should have a substantial positive effect on women's representation and role in the decision-making process at all levels of government (Fitzgerald, 2010, p.4). 


\section{Nancy Baraza}

The Constitution in Article 2 (5) and (6) adopts international treaties ratified by Kenya before 2010. Notable among the conventions is the Convention on the Elimination of All Forms of Discrimination against Women (CEDAW), which calls upon States Parties to take all appropriate measures to eliminate discrimination against women in the political and public life (Nzomo, 2016, p.45). KameriMbote and Muriungi rightly argue that the 2010 Constitution heralded a new era, as it re-envisioned the governance charter by revamping fundamental rights and freedoms and providing for far-reaching institutional reforms. It expanded the purview of and made provision for affirmative action and social justice (Kameri-Mbote \& Muriungi, 2016, p.93). Mutunga posits that the Constitution is a radical document, which looks to a future that is very different from the past in its values and practices. It seeks to make a fundamental change from colonialism and repressive post-colonial years of independence (Mutunga, 2015, p.5). He further states that Kenya has moved from a past characterized by much, which was arbitrary and unequal in the operation of the law to a present and a future in a constitutional state where state action must be such that it is capable of being analyzed and justified rationally. The idea of a constitutional state presupposes a system whose operation can be rationally tested against or in terms of the law (Mutunga, 2015, p.5).

In stark contrast to the independence Constitution, the 2010 Constitution sets up an institutional framework of checks and balances, including through strengthened judicial review, something for which women activists actively lobbied (Baraza, 2018, p.3). In a nutshell, the Constitution potentially provides an enabling institutional architecture for the realization and protection of women's rights and gender equality principles. Such was the extent of its reform in favor of gender equality that the 2010 constitution is known informally as "the women's constitution" (Baraza, 2018, p.3). Additionally, the Constitution spells out how the judiciary is to interpret its robust Bill of Rights. Article 259 states that the Constitution shall be interpreted in a manner that promotes its purposes, values, and principles; advances the rule of law, and the human rights and fundamental freedoms; permits development of the law; and contributes to good governance (Mutunga, 2015, p.5).

There is no doubt that the Constitution offers the courts an opportunity to break from the old way of judicial interpretation, which failed to consider societal values as the basis for decision-making. The courts are expected to "liberate themselves from previously self-imposed restraints that undermined their position in the equilibrium of governmental power" (Mutunga, 2015, p.5). Such restraints included a legal culture in which judges and lawyers failed to relate their actions to the purposes of a Constitution in any functional democracy. Muigai notes that the Kenyan courts have previously adopted a positivist approach to judicial interpretation, which ignored constitutional values such as equality and social justice (Muigai, 2004, p.45).

The realization of gender equality under the Constitution is a possibility but it requires innovative and transformative judicial decision-making by the judiciary. The framers of the 2010 Constitution were alive to feminist approaches to the 
interpretation of the Constitution when they entrenched a method of interpretation in the constitution (Baraza, 2018a, p.75). The constitutional requirement for transformative judicialism seeks to diminish the difficulty that courts have previously faced by setting parameters for purposive interpretation. According to Baraza (2018a, p.76), this interpretive approach considers societal values and requires judges to be the guardians of the socio-political transformation project of the country. Difficulties in judicial interpretation require all provisions of the Constitution to be construed according to the doctrine of interpretation that the law is always speaking, thus avoiding doctrinal and textual capture (Mutunga, 2015, p.5).

The argument in this chapter is that the Constitution's normative provisions, coupled with the imperative of purposive interpretation placed on the judiciary, offer an excellent opportunity for the judiciary to move away from the past and uphold gender equality and the human dignity of all people. However, the chapter is also aware that the purposive role of the judiciary faces threats not just from itself but from parliament and executive arms of government, as will be discussed elsewhere in the chapter. The following section examines the meaning and theoretical perspectives of transformation.

\section{Transformation}

The Cambridge dictionary, 1995 edition, defines transformation as "a complete change in the appearance or character of something or someone, especially so that that thing or person is improved." This definition of the concept of transformation is reflected in the design and spirit of the Kenyan Constitution, considering the historical inequalities in Kenya and the intention of the constitutional purpose of shaping a new and different future that is anchored in social justice. Klare, who coined the term "transformative constitutionalism," says that transformative constitutionalism means a long-term project of constitutional enactment, interpretation and enforcement committed (not in isolation, of course, but in a historical context of conducive political developments) to transforming a country's political and social institutions and power relationships in a democratic, participatory, and egalitarian direction (Klare, 2012, p.146). He further states that transformative constitutionalism is anchored by progressive jurisprudence from the judiciary and observance of the Constitution by other state organs, and indeed all Kenyans (Klare, 1998, p.152). In this view, achieving equality in the context of transformation requires an understanding by lawmakers, judges, and those in charge of institutions of society that equality forms the center of the constitutional vision and promise of transformation, as well as an understanding of equality as a value and equality as a right.

Langa also argues that transformation is a social and an economic revolution, while. Albertyn and Goldblatt perceive transformation to be a movement from the one side of the bridge to the other, and this would have to be radical movement which requires a complete reconstruction of the state and society, including a redistribution of power and resources along egalitarian lines. The challenge in 
achieving equality within this transformation project involves the eradication of systemic forms of domination and material disadvantage based on race, gender, class and other grounds of inequality. It also entails the development of opportunities which allow people to realize their full human potential within positive social relationships (Langa, 2017, p.353).

Transformative judicial interpretation is premised on the concept of transformation. It draws from Ronald Dworkin's theory of constructive interpretation, which posits a principle-based mode of interpretation (Zegrebelsky, 2001, p.621). Dworkin's principle-based approach to interpretation considers societal values and principles as foundational to judicial decision-making. This approach faults the positivist approach, which considers interpretation as merely guided by rules, precedents, and procedures, and judges as mere mouthpieces of the legislature (Zegrebelsky, 2001, p.622). The positivist approach, however, remains common among judges and lawyers, especially in the common law systems, and dominated judicial thought among most Kenyan judges, especially before 2010. Dworkin's approach leads to transformative constitutionalism, the very expectation of the constitution of Kenya. A transformative Constitution and its attendant transformative constitutionalism are both about a change from a status quo that is neither acceptable nor sustainable (Mutunga, 2015, p.5).

The Constitution of Kenya is transformative and aims at changing the society to make it more egalitarian and alive to gender equality. Although the word "transformation" does not appear in the Constitution of Kenya, it has now been widely accepted that the Constitution aims at radically changing or transforming the political, social, cultural, and economic space in Kenya (Mutunga, 2015, p.5).

\section{Judicial decisions on gender issues in Kenya prior to 2010}

Patriarchal decision-making in matters of succession arising out of a narrow judicial interpretation of the law by the courts was rampant in the judiciary prior to 2010. Property of a deceased patriarch customarily devolved to the male members of a household, principally the sons of the deceased (Kamau, 2015, p.4). Where a deceased person had no son, such property devolved to the deceased person's brothers. It was assumed that girl children or women could not inherit, at least under customary law, on the basis that women never really belong to any clan, as they move from their clan of birth to their husband's clan. Most customs only allow some inheritance to unmarried daughters and divorced women when they return to their parents' home, but even in such instances, the inheritance given to such women is small compared with that of sons or men. These practices serve to entrench gender inequality further, as they peg what a person may inherit from their parents' estate on their gender without referring to other relevant factors (Baraza, 2008, p.5).

An examination of some cases demonstrates the skewed nature of judgments, mostly against women, prior to 2010. In the case of Mary Rono $v$ Jane Rono $\mathfrak{E}$ another, [2008] 1 KLR 803, for instance, the High Court awarded a lesser share of the deceased father's estate to the girls and a bigger share to the brothers, agreeing 
with the brothers that the girls would get married elsewhere and get property from their husbands (Baraza, 2008, p.5). The sons had based their argument on tribal culture, which did not permit girls to inherit land from their father. Upon appeal, the Court of Appeal reversed the High Court decision, noting that the law of succession in Kenya did not discriminate against girls. Although the High Court decision was overturned by the Court of Appeal in Eldoret High Court Civil Appeal 66 OF 2002), [2005] eKLR, the case reflected the common judicial attitude at the time.

Regarding division of matrimonial property, until 2013, when the Matrimonial Property Act was enacted, Kenya relied on an old 1882 piece of legislation-the Married Women Property Act (MWPA) of England-to find relief for women seeking a share of matrimonial property. The Act laid the ground for a consideration of women as legally distinct individuals, contrary to the situation prevailing under the doctrine of coverture that underpinned the old English law (KameriMbote \& Muriungi, 2016, p.45). Judicial construction of the provisions of the MWPA presented mixed but dismal results in terms of delivering property rights for married women. For instance, in Echaria v Echaria, Civil Appeal 75 of 2001 (2007) eKLR (C.A.), the court held that a married woman had to prove financial contribution in order to get a share of the matrimonial property upon divorce. Given the injustice and harshness visited on married women, who mainly performed unpaid household chores, the court in Kivuitu v Kivuitu Civil Appeal 26 of 1985, eKLR had earlier remarked obiter that contribution need not be financial.

According to Kameri-Mbote and Muriungi, there were many instances of women and children being disinherited when male members of households or husbands opted to dispose of the matrimonial property with the concurrence of the courts (Kameri-Mbote \& Muriungi, 2016, p.45). This was the position in Jacinta Wanjiku Kamau v Isaac Kamau Mungai, Civil Appeal 59 of 2001 (2006) 59 K.L.R, where the court emphasized that the husband was under no legal obligation to seek the consent of the wife before disposing of the land that was used as matrimonial property as long as it was registered solely in the husband's name. Though the wife worked to maintain the land, she was only awarded 0.25 acres of the land to enable her to fend for herself and the eight children. A similar holding regarding the interest of a married woman was made in Margaret Mumbi Kagiri $v$ Kagiri Wamairwe 83 others. (2007) 181 K.L.R. 8 (C.A. K).

In the case of Kamore $v$ Kamore [2000] 1 EA 80, the court considered the principle or doctrine of trust. It held that there was a need to show evidence of contribution by a spouse and thus departed from Nderitu. The court held that it could not make a finding of a resulting trust in favor of the wife without evidence of either express or implied intention of the donor. It further noted that there was a need to demonstrate contribution for a share of matrimonial property to vest and that section 17 of the MWPA gave no power to the court to pass any proprietary interest from one spouse to another (Kameri-Mbote \& Muriungi, 2016, p.45).

In Kimani $v$ Kimani, [2000] 1 EA 80, 81, 85, the parties had undergone a Christian marriage and were blessed with two children but later lived separately after strains in their relationship. After alleged battery, the wife left the 


\section{Nancy Baraza}

matrimonial home for good and later filed for divorce. Within the pendency of the divorce proceedings, she brought an application for a share of property. During trial, the husband was able to prove that he contributed to the purchase of the property alone. Kuloba J, unconvinced that the wife had made any financial contribution toward the acquisition of the property, held that contribution must be proved on evidence (Kameri-Mbote \& Muriungi, 2016, p.45). The trial equated the behavior of the wife wanting to share in the matrimonial property with her "riding on the husband's back with her hands in his pocket." This decision was reversed by the Court of Appeal, on the basis that the trial judge was biased generally against women, and remitted to another trial judge for retrial.

Customary marriages in their several variants have existed in Kenya alongside their formal and religious counterparts. However, customary law generally, and customary marriages in particular, have, until the 2010 constitution, been assigned an inferior status to civil and religious marriages (Osogo \& Ahaya, 2015, p.47). Customary marriages include polygamous unions, woman-to-woman marriages, and widow inheritance, among others. Subjugation of customary marriages, expressed through court decisions, has previously caused a lot of suffering to the concerned parties. From the onset of colonialism, courts have entrenched a dim view of African forms of marriage, and in most cases, they have declared them either immoral or not worth being called marriages (Cotran, 1983, p.42).

In $R v$ Amkeyo [1917] 7 EALR 14, the question that arose during the trial was whether a woman married under African customary law could testify against her husband in a criminal case in which she was the only witness. The husband had been charged with stealing an animal skin, which he hid in the matrimonial house. Applicable common law deemed a husband and wife as one person, and neither could be compelled to give evidence against the other. In this case, the court found that the African wife could give evidence against her husband because the two did not meet the criteria of being considered married. According to Hamilton, CJ, a wife married under African customary law was not a legal wife or spouse under the formal law. Consequently, the court compelled her to give evidence against her husband. This case is indicative of how African customary law was degraded to the bottom of the legal rules hierarchy and made way for judicial precedence, ordinances, and statutes (Osogo \& Ahaya, 2015, p.47).

In Maria Angoi v Macella Nyomenda, Civil Appeal No.1 of 1981(unreported), the court was faced with the question of whether a woman-to-woman marriage custom among the Kisii tribe was repugnant to justice and morality. A womanto-woman marriage is a customary practice whereby a woman whose husband is dead "marries" another woman and chooses a male figure from her husband's clan to sire children for the dead husband. The High Court held that the practice was repugnant to justice and morality, since it prevented the other woman from freely choosing whom to marry. Thus, there was no marriage. The decision did not consider the circumstances of the local community and the intention underlying the woman-to-woman practice in African communities, whose perpetuity was guaranteed through children (Baraza, 2018, p.71). 


\section{Judicial decisions since 2010}

Since the promulgation of the Constitution in 2010, some Kenyan courts have begun to embrace transformative and purposive judicial interpretation of cases and this has led to significant strides toward realizing gender equality in marriage, access to matrimonial property, protection against gender-based and domestic violence, and inheritance. Courts have been developing jurisprudence with some radical judgments that have upheld the principles of equality (Kameri-Mbote \& Muriungi, 2016, p.45). The following part discusses some of these cases.

\section{Inheritance}

Since 2010, the courts have been emphatic that all children, whether male or female and irrespective of their marital status or financial status, are eligible to inherit in equal shares unless they indicate to the court that they do not wish to inherit. These decisions have been made as a result of women challenging being disinherited by their brothers and uncles. In re Estate of Francis Mbaria (Deceased) [2018] eKLR, one of the female children filed an application for revocation of a grant that had been issued and confirmed to one of the male children (her brother). She protested the mode of distribution of the estate of her deceased father, citing unfairness, and principally on the ground that the female children had each been allocated 1 acre of land, unlike the male children, who were given a bigger portion. The brothers had argued that the female children were happily married and had property of their own and thus ought to be satisfied with the 1 acre of the land that they had been allotted. The court, in considering the argument that married female children should not inherit from their parents, as doing so is unfair to their brothers, rejected the argument as being based on backward and patriarchal customs. Accordingly, the court held that all the children were entitled to an equal share (Kameri-Mbote \& Muriungi, 2016, p.45).

Similarly, in Joshua Cheruiyot v Rachel Korir [2017] eKLR, six sisters in their old age who had been totally disinherited by their brothers were able to successfully apply for revocation of grant and obtain a declaration that all the children were to have an equal share of their deceased father's property. The rationale for providing for equal inheritance for both male and female children in the spirit of gender equality was aptly put by Justice Kimaru in Peter Keingati $\& 4$ Others Vs Ann Nguthi $\mathbb{E} 3$ Others [2014] eKLR, where he stated that due to "the promulgation of the constitution 2010, particularly Article 27 that prohibits discrimination of persons on the basis of their sex, marital status or social status, among others, the time has now come for those discriminative cultural practices against women be buried in history."

\section{Gender-based violence (GBV)}

Gender-based violence (GBV) is one of the most prevalent human rights violations in Kenya. Violence against women is perhaps the most widespread and 


\section{Nancy Baraza}

socially tolerated human rights violation, cutting across borders, race, class, ethnicity, and religion. GBV in Africa, as elsewhere in the world, is a complex issue that has at its root structural inequalities between men and women, young and old. This results in the persistence of power differentials between the sexes. World Bank research has indicated that in 2014, 22\% of Kenyan women and $19 \%$ of Kenyan men agreed with the statement that if a wife went out without informing her husband, he would be justified in hitting or beating her. The social norms justifying GBV in Kenya appear to have been changing: the share of the population who agreed with the above statement fell by about half between 2003 and 2014 (DHS, 2018). However, in 2014, about half of all women (45\%) between the ages of 15 and 49 reported having experienced physical violence (World Bank, 2018).

The Kenyan state has, in most cases, perpetrated or tolerated violence against women, through either action or non-action, by prioritizing custom or tradition over the respect of fundamental freedoms and rights belonging to women. Previously, there had been little commitment from the state to protect citizens from the vice of GBV; the existing criminal laws were not adequate to address the issue, and in any event, they were ignored in favor of customs by law enforcers. The Constitution recognizes several important general principles that are of importance to gender equality and that have a general bearing on GBV in the country (Aura, 2015). These principles were either not given recognition by the previous Constitution or were given inadequate treatment.

A significant development consequential to the 2010 constitution was the enactment of the Protection from Domestic Violence Act of 2015. The Act is fundamental, as it is the only piece of legislation that addresses violence within the family set-up. The Constitution at Article 29 provides expressly for the freedom and security of the person. Article 29 (c) protects all persons from any form of violence from either public or private sources, and Article 29 (d) prohibits any manner of torture, whether physical or psychological. The Constitution further places the duty on the state and its organs to ensure that the Bill of Rights is followed. Article 21 (3) of the Constitution places this duty on all public officers. The state and public officers are required to address the needs of vulnerable groups within the society, including women, older members of the society, persons with disabilities, children, youth, members of minorities or marginalized communities, and members of particular ethnic, religious, or cultural communities (Aura, 2015, p.4). Since 2010, the courts have been developing jurisprudence in the area of GBV. In NML v Peter Petrausch [2015] eKLR, Rika J held that "gender-based violence is the most prevalent human rights violation in the world. No other form of sex discrimination violates so many fundamental rights as articulated in the 1948 United Nations Universal Declaration of Human Rights". The claimant, in this case, was a domestic worker who was consistently sexually harassed and threatened by her employer. The case indicates the gravity of domestic violence matters.

The recent case of C.K. (A Child) Through Ripples International as Her Guardian and Next Friend) $\mathcal{E} 11$ Others v. Commissioner of Police/Inspector General of The 
National Police Service $\mathcal{E} 3$ Others [2013] eKLR is significant. In this case, the High Court's finding that the failure of the police to enforce Section 8 of the Sexual Offences Act 2006 effectively infringed upon the petitioners' right to equal protection and benefit of the law, contrary to Article 27 (1) of the Constitution of Kenya, 2010, was a step in the right direction. Also, the court observed that by failing to enforce existing defilement laws, the police contributed to the development of a culture of tolerance for pervasive sexual violence against girl children with impunity (Aura, 2015, p.4).

On the other hand, Wakiaga J in Republic v Johana Mweni [2018] eKLR, while commenting on the issue of domestic violence, stated that

The court is alive to the rise in the number of deaths arising out of domestic violence or in the family setting and therefore any Judgement/Sentence meted out by the court should send a warning that the home is a city of refuge and not a place where one has to be on his/her guard as was in the case herein.

These are profound sentiments by the courts, not previously known for regarding domestic violence, because it afflicts mostly women, as a serious offense, and demonstrate transformative decision-making. Within a patriarchal society, it should be noted that although the Protection from Domestic Violence Act of 2015 is a great milestone in addressing GBV, the vice still persists due to ignorance of the law among many Kenyans and the perseverance of socio-cultural habits that still condone such violence.

\section{Sharing of matrimonial property}

Matrimonial property is now governed by the Matrimonial Property Act of 2013. This legislation replaced the old English Married Women's Property Act of 1882, which was introduced in Kenya in the colonial period as an Act of general application. The 2013 law recognizes non-monetary contributions, such as housework, toward the acquisition of matrimonial property. The introduction of non-monetary contributions in consideration of marital property distribution upon divorce is a shift from earlier case law, which was seen in Peter Mburu Echaria vs. Priscilla Echaria [2007] eKLR before the enactment of this Act, and set out the direct financial contribution of a spouse in a marriage as the basis of determination of the distribution of marital property in divorce cases (Kameri-Mbote \& Muriungi, 2016, p.17). In ZWN v PNN [2012] eKLR, the court shared the properties equally between the spouses.

\section{Equality in marriage}

Courts have also since 2010 affirmed equality of parties in a marriage, a departure from the past. In the case of Agnes Nanjala -vs-Jacob Goes, Appeal No. 127 of 2011 (UR), the court affirmed equality of spouses and appreciated that the 
Constitution guarantees equality of parties to a marriage and both are entitled to equal rights at the time of the marriage during the marriage and at the dissolution of the marriage.

There have also been progressive court decisions on matters of the rights of women in customary marriages. Courts had previously failed to protect women in polygamous unions. They had also been inconsistent in articulating the position of customary practices such as the much-respected woman-to-woman marriage, which is a reality among several communities (Baraza, 2018a, p.71). Departing from the court's attitude in $R$. vs. Amkeyo discussed earlier, the courts have dealt positively with polygamy and the institution of woman-to-woman marriage. In the case of Eunita Geko $\mathcal{E}$ Another v Philip Orinda Petition No. 237 of 2014 [2015] $E K L R$, the court upheld the validity of a woman-to-woman marriage under the Kuria customs, a clear departure from the decision in Gisege Angoi v Macella Nyomenda, discussed earlier, in which the court had declared woman-to-woman marriage immoral and repugnant to morality. The "repugnancy" clause in the Kenyan Judicature Act, chapter 8 of the Laws of Kenya, was a colonial requirement as a criterion for the application of African customary laws.

\section{Threats to the judiciary's efforts to uphold gender equality}

Although the Constitution has the potential for realization of gender equality, customary law, which has historically held de facto sway over formal law (Hallward-Driemejer \& Hasan, 2012), still threatens to lessen the impact of the transformative constitution, especially in matters of inheritance of land by women. Kamau (2011a, p.4) acknowledges that customary law contains aspects that often run counter to principles of gender equality and non-discrimination espoused in the constitution, especially the right of women to inherit equally with men. Indeed, World Bank research (World Bank, 2015) has also found that Kenya is indeed notable as one of a minority of African countries where there are formal inheritance rights. However, the research also notes that though the Constitution establishes non-discrimination articles, some subordinate statutes do have lingering gender biases. For example, the Law of Succession Act distinguishes between male and female surviving spouses. It is also worth noting that since the promulgation of the Constitution, the right guaranteed to women to inherit land from their parents has hardly benefited them due to hostility from their male siblings against allowing them to inherit, basing their arguments on customary practices (Kamau, 2011b, p.4).

Although the judiciary has been transformative in its decisions, the legislature and the executive pose a real threat to its efforts, particularly given that one of the key distinctive features of the constitution relating to gender equity is the not more than two-thirds gender rule, which is meant to ensure fair representation of women in the legislature and appointed positions. The provision has been repeatedly undermined and contested by both the legislative and executive branches, and no enabling legislation has been enacted or implemented. This spells real danger to women's representation in elective and appointive positions envisaged 
under the constitution. Further, Kenya is currently considering constitutional amendments, and women fear that the entire not more than two-thirds gender rule might be repealed if men's current attitude toward it is anything to go by (Kamau, 2011b, p.4).

\section{Conclusion}

This chapter set out to examine the nature of judicial decisions on gender equality since the promulgation of the constitution of Kenya 2010. It has highlighted the normative and procedural provisions that are of importance for equality generally and for gender equality in particular. Further, it explored the duty that the constitution imposes on the courts in decision-making. It examined relevant decided cases before the 2010 constitution and demonstrated how narrow approaches to interpretation by the courts sustained gender inequality. It noted that the courts are under an obligation to depart from the positivist approach of the past when making decisions that touch on the rights of men and women. A significant part of this chapter was then devoted to an analysis of jurisprudence on gender equality on disparate areas of law as emanating from the various courts of law. The analysis has shown that in the majority of cases, the courts have been transformative and bold in asserting themselves and giving effect to constitutional provisions on gender equality. It also noted that although the judiciary has been transformative, both the legislature and the executive threaten to derail equal participation of men and women in all spheres of life.

\section{References}

Aura-Odhiambo, R.A. (2015), Situational Analysis and the Legal Framework on Sexual and Gender-based Violence in Kenya: Challenges and Opportunities. Nairobi: National Council for Law Reporting.

Baraza, N. (2008). Lost Between Rhetoric and Reality: What Role for the Law and Human Rights in Redressing Gender Inequality? Kenya Law Review Journal, 11, 16-27.

Baraza, N. (2018a). Supreme Court of Kenya Advisory Opinion on the Two-Thirds Gender Principle: A Critique Through Dworkin's Constructive Interpretation. East African Law Journal, 150, 150-165.

Baraza, N (2018b). The Institution of Woman to Woman Marriage in Kenya: Navigating Between Culture and Human Rights. Africa Nazarene University Law Journal, 6(2):71-91

Cotran, E. (1983). The Development and Reform of the Law in Kenya. Cambridge: Cambridge University Press.

Demographic Health (DHS) (2018). The Kenya National Bureau of Statistics (KNBS), https://dhsprogram.com/pubs/pdf/fr308/fr308.pdf.

Fitzgerald, J. (2010). The Road to Equality? The Right to Equality in Kenya's New Constitution. The Equal Rights Review, 5, 55-69.

Hallward-Driemeier, M., \& Hasan, T. (2013). A Copublication of the Agence Franceise de Developpment and the World Bank. Available at www.worldbank.org 


\section{Nancy Baraza}

Kamau, W. (2011a). Customary Law and Women's Rights in Kenya. http://theequalityef fect.org/wp-content/uploads/2014/12/CustomaryLawAndWomensRightsInKenya.pdf

Kamau, W. (2011b). Women Judges and Magistrates in Kenya: Challenges, Opportunities and Contribution. In U. Schultz \& G. Shaw (eds.), Gender and Judging. Overview and Synthesis (pp. 167-190). Oxford: Hart.

Kamau, W. (2015). Women's Representation in elective and Appointive Offices in Kenya: Towards Realization of The Two-Thirds Gender Principle. In M.K Mbondenyi, E.O. Asaala, T. Kabau, \& A. Waris (eds.), Human Rights and Democratic Governance in Kenya: A Post-2007 Appraisal. Pretoria University Law Press (PULP). https://www .pulp.up.ac.za/edited-collections/human-rights-and-democratic-governance-in-kenya -a-post-2007-appraisal

Kameri-Mbote P. (2018). Constitutions as pathways to gender equality in Plural legal systems. Oslo Law Review, 5, 21-41.

Kameri-Mbote, P., and Kabira, N. (2018). Woman of Law: Kenyan Women's Triumph in the Constitution of Kenya. In W. Kabira, P. Kameri-Mbote, N. Kabira, \& A. Meroka (Eds.), Changing the Mainstream: Celebrating Women's Resilience. Nairobi: African Women Studies Centre, University of Nairobi.

Kameri-Mbote, P., and Muriungi, M. (2016). Much ado about Nothing; A Critical analysis of the Matrimonial Property Law in Kenya. Zanzibar Yearbook Law Journal, 6, 71-102.

Klare, K.E. (2012). Legal Culture and Transformative Constitutionalism. South African Journal on Human Rights, 14(1), 146-188.

Langa, P. 2017. Transformative Constitutionalism. 17 Stellenbosch L. Rev. 351, 2006, 351-360.

McCullough, A., Simbiri, F., \& Wanjala, B. (2016). Women and Power: Shaping the Development of Kenya's 2010 Constitution. London: Overseas Development Institute.

Muigai, G. (2004). Political Jurisprudence or Neutral Principles: Another Look at the Problem of Constitutional Interpretation. The East African Law Journal, 1, 40-60.

Mutunga, W. (2015). The 2010 Constitution of Kenya and Its Interpretation: Reflections from the Supreme Court's Decisions. Speculum Juris 6, 29(1), 1-20.

Nzomo M. (1991). The Role of Women in Politics and Public Decision Making Positions. Paper presented at the United Nations Expert Group Meeting on the Role of Women in Politics and Public Decision Making, Vienna, Austria, 21-24 M. http://erepository .uonbi.ac.ke/handle/11295/46061

Nzomo M, (1993). The Gender Dimension of Democratization in Kenya: Some International Linkages. Alternatives, 18(1), 61-74. University of Nairobi.

Nzomo, M. (2016). The Status of Women's Human Rights in Kenya and Strategies to Overcome Inequalities. Cambridge: Cambridge University Press.

Nzomo M. (2018). Gender and Governance in Kenya: Women's Journey Beyond Numbers. In Changing the Mainstream: Celebrating Women's Resilience (Kabira W, Kameri-Mbote P, Kabira N and Meroka A eds). Nairobi: African Women Studies Centre, University of Nairobi.

Osogo A.J., \& O. Ahaya. (2015). The Wretched African Traditionalists in Kenya: The Challenges and Prospects of Customary Law in the New Constitutional Era. Strathmore Law Journal, 1(1), 41-58.

Patricia Kameri-Mbote, P. (2016). The quest for equal gender representation in Kenya's Parliament: Past and present challenges. In Japhet Biegon (ed.), Gender Equality and Political Processes in Kenya (39-64). Strathmore University Press.

Procter, P. (1995). Cambridge International Dictionary of English. Cambridge: Cambridge University Press. 
World Bank, 2015. Women, Business and the Law Report. Available at http://pubdocs. worldbank.org/en/810421519921949813/Women-Business-and-the-Law-2016.pdf

World Bank, 2018. Http:/documents 1.worldbank.org,/pdf/kenya-poverty-and-gender -assessment-2015-2016-reflecting-on-a-decade-of-progress-and-the-road-ahead.pdf

Zegrebelsky, G. (2001). Ronald Dworkin's Principle-based Constitutionalism. London: Oxford University Press.

\section{Constitutions}

The Constitution of Kenya 2010

The Independence Constitution of Kenya 1963

\section{Statutes}

Judicature Act, chapter 8 of the Laws of Kenya

Matrimonial Property Act of 2013.

Protection from Domestic Violence Act of 2015

2014 Marriage Act, the 2013

\section{Cited cases}

Agnes Nanjala -vs- Jacob Goes, Appeal No. 127 of 2011 (UR)

C.K. (A Child) Through Ripples International as Her Guardian and Next Friend) \& 11 Others v. Commissioner of Police/Inspector General of The National Police Service $\& 3$ Others [2013] eKLR.

Echaria v Echaria, Civil Appeal 75 of 2001 (2007) eKLR (C.A.).

Eunita Geko \& Another v Philip Orinda Petition No. 237 of 2014 [2015] EKLR.

Joshua Cheruiyot v Rachel Korir [2017] eKL.,

Kimani v Kimani, [2000] 1 EA 80.

Kamore v Kamore [2000] 1 EA 80.

Lucy Wanjiru Kariuki v Republic, Criminal Revision 12 of 2014 [2015] eKLR.

Maria Angoi v Macella Nyomenda, Civil Appeal No.1 of 1981(unreported).

Margaret Mumbi Kagiri v Kagiri Wamairwe\& 3 others. (2007) 181 K.L.R. 8 (C.A. K).

Mary Rono v Jane Rono \& another, [2008] 1 KLR 803.

Mary Rono v Jane Rono \& another, Eldoret High Court Civil Appeal 66 OF 2002), [2005] eKLR,

MJK v FML Civil Suit 39 of 2012.

NML v Peter Petrausch [2015] eKL.,

Peter Mburu Echaria vs. Priscilla Echaria [2007] eKLR.

Peter Keingati \& 4 Others Vs Ann Nguthi \& 3 Others [2014] eKLR.

Republic v Amkeyo [1917] 7 EALR 14.

Republic v Johana Mweni [2018] eKLR.

Republic v Collet Wafula [2016] eKLR.

Re Estate of Francis Mbaria (Deceased) [2018] EkL.

Supreme Court of Kenya Advisory Opinion No. 2 of 2011(In the Matter of Interim Independent Electoral Commission [2011] eKLR. 